\title{
The Mediator Roles Of Attitude Toward The Web Site And User Satisfaction On The Effect Of System Quality On Net Benefit: A Structural Equation Model On Web Site Success
}

\author{
Mustafa Emre Civelek, PhD Candidate \\ Istanbul Commerce University, Turkey \\ Hüseyin Ince, $\underline{\mathrm{PhD}}$ \\ Gebze Technical University, Turkey \\ Ahu Tuğba Karabulut, PhD \\ Istanbul Commerce University, Turkey
}

doi: 10.19044/esj.2016.v12n10p61 URL:http://dx.doi.org/10.19044/esj.2016.v12n10p61

\begin{abstract}
The purpose of this study is to examine the mediator roles of attitude toward the web site and user satisfaction on the effect of system quality on net benefit. A new conceptual model for web site success is developed based on previous models in the literature. System quality is one of the most important antecedent of perception of net benefit for customers of B2C sites. The effect of system quality on net benefit has been through user satisfaction in the literature. Some models included attitude toward the web site dimension in the same level with user satisfaction. Therefore, the research model suggested these two variables play mediator roles on the effect of system quality on net benefit. A structural equation model is used to analyze this model. It is statistically proved that attitude toward the web site and user satisfaction play mediator roles on the effect of system quality on net benefit.
\end{abstract}

Keywords: Website Success, B2C, User Satisfaction, E-Commerce

\section{Introduction}

The purpose of this study is to examine the mediator roles of attitude toward the web site and user satisfaction on the effect of system quality on net benefit. An new model for web site success is developed based on models in the literature. Perception of the users about net benefit fundamentally represents the success of the website.

When the financial and social influences of internet are explored in the micro perspectives of business and commerce, it is observed that internet 
has caused major changes in structures and cultures of companies. Two main pressures on today's companies are more powerful customers and increased competition. After the beginning of 2000, web sites have played roles in people's lives and improved knowledge and consciousness of customers. Nowadays, comments and complaints of customers about companies in social media platforms have threatened companies and given chances to them to defeat their competitors. The second major pressure on companies is increased competition. The competition has been increasing since the beginning of 1990s due to adapting the competitive free market economy. Since the supply is greater than demand in the market, many companies face competition (Sözer, 2009).

Online shopping companies selling products through their web sites are affected by the financial and social aspects of the internet. Since the main platform for these companies to communicate with their customers is their websites, determining internet users' satisfaction level and attitude toward online shopping websites is very important for these companies.

The websites of B2C businesses are the main channel to contact with their customers and provide the opportunity to reach global markets. On the other hand, some businesses create B2C websites as an alternative to the traditional supply chain. Recently this alternative has become an obligation rather than an option for retailer businesses (Tang \& Huang, 2008).

\section{Literature Review}

Commerce can be defined as the exchange of money, goods and services between a buyer and a seller. Electronic commerce (e-commerce) is defined as performing this exchange by means of the internet technologies. E-commerce requires using internet for commercial activities. Production, purchasing, marketing and sales are performed in an electronic platform (Canpolat, 2001).

The concept of e-commerce has been widely used due to the economic growth and improvement of information systems technologies. The concept of e-commerce has been adopted quickly by companies due its advantages such as relatively low costs, elimination of time and space limitations, interactive simultaneous transmission of the contents by many people (Sarısakal \& Aydin, 2003).

In the literature, e-commerce companies are classified whether customers and sellers are institutions or individuals. When buyers and sellers of e-commerce companies are both institutions, it is called business to business (B2B). When buyers are individuals and sellers are institutions, it is called business to customer (B2C). When buyers and sellers are both individuals, it is called customer to customer (C2C). Also, e-commerce can be defined as the exchange of money, goods and services between buyers 
and customers by means of internet. There are also many websites which fit to this definition rather than others. Since the classification of e-commerce based on buyers and sellers is a general classification, it does not involve all types of e-commerce. B2C which this study focuses on can be defined as follows: It is the name of the e-commerce application platform where marketing, sales and distribution of companies are performed by means of computer networks (Laudon \& Traver, 2012).

B2C applications are activities which exclude B2B have been widely used and reached the largest trade volume. B2C helps customers to reach and buy many products and services by connecting internet from their homes and offices without time and location limitations. Internet gives an opportunity to producers and customers to meet. Since internet decreases the number of mediators and costs, reaching customers through B2C channels becomes attractive for companies (Deniz, 2001).

Five step purchasing process of customers in B2C websites is explained as follows (Hsia, Wu, \& Li, 2008):

1- Need recognition: Users determine their needs and plan how to satisfy these needs.

2- Information search: Users begin to search for resources which can satisfy their needs and collect information.

3- Evaluation of alternatives: Users use the collected information to choose among the alternative products.

4- Choice: Users make decisions to order and purchase the products that they chose.

5- Post-purchase: Users use after-purchase services provided by B2C websites.

There are many factors in B2B websites which influence purchasing decisions of customers. These can be classified as financial, demographic, technical, social, cultural, psychological and marketing factors (Pilik, 2013).

\section{Conceptual Framework}

The most important component of an e-commerce business is its website. The success of the website is the most important factor which determines the success and survival of the business. The most important factor which determines the success of the website is the level of customer preference. The dimensions which determine the website preference are users' attitudes toward the website and their satisfaction. Since this study focuses on B2C, real purchasing experiences of users' from the websites are analyzed. These two dimensions create a perception of net benefit for customers eventually. Users' perception of net benefit represents the success of the website. 
The first base model for creating the conceptual model in this study is DeLone and McLean IS success model (Delone \& McLean, 1992). The researchers (1992) have suggested six fundamental dimensions which determine success of information systems as it is shown in Figure 1 (DeLone \& McLean, 1992). Several researchers working in the field of information systems criticized DeLone and McLean IS success model and suggested some changes. Thus, DeLone and McLean (2003) developed Updated DeLone and McLean IS success model (Delone \& McLean, 2003).

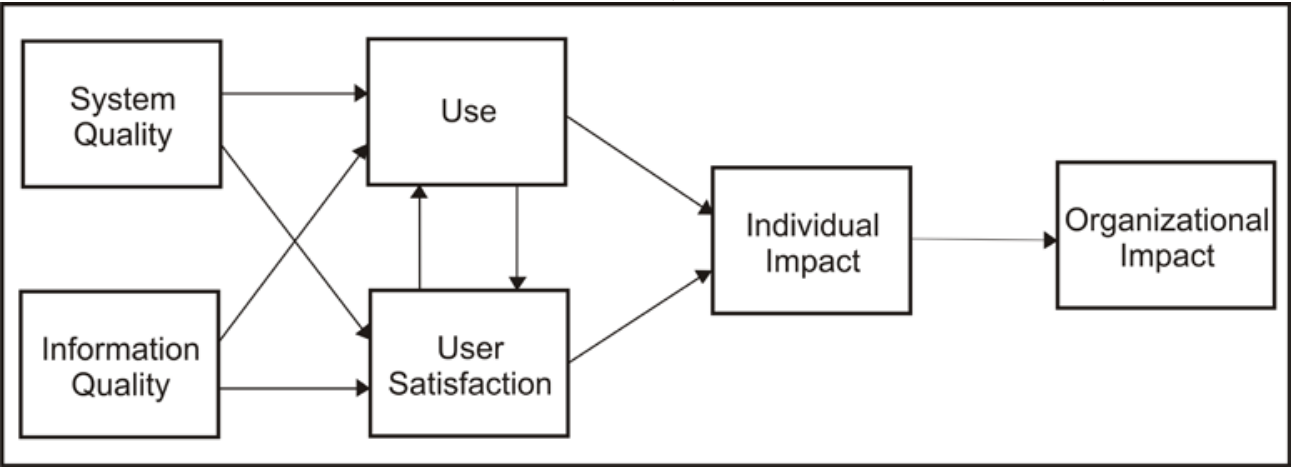

Figure 1. DeLone and McLean IS Success Model (1992) (Petter et al., 2008, p. 237)

DeLone and McLean added service quality, intention of use, net benefit dimensions in the updated model whereas they removed use, individual impact, organizational impact dimensions as it is shown in Figure 1 \& 2. (Petter et al., 2008). DeLone and McLean IS model is the most cited model in the literature.

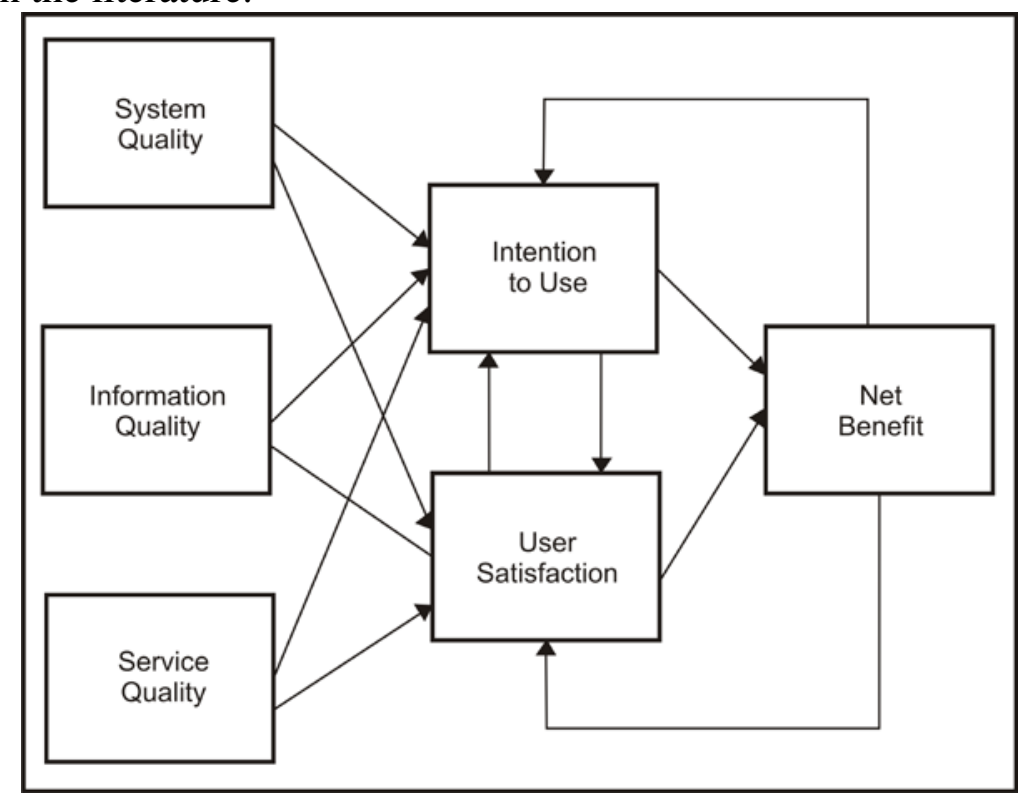

Figure 2. Updated DeLone and McLean IS Success Model (2003) (Delone \& McLean, 2003, p. 24). 

2010):

The three main contributions of this model are as follows (Mira,

1- Classifying all evaluating criterias of the literature,

2- $\quad$ Evaluating all stakeholders,

3- $\quad$ Presenting how these factors interact with each other in the structure.

Another sample model which is used for building the conceptual model of this study is Chen et al.'s (2013) model (Success of Electronic Web Sites) developed by Jengchung V. Chen, Duangjai Rungruengsamrit, T. M. Rajkumar and David C. Yen in 2013. This model which is shown in Figure 3 is based on Updated DeLone and McLean IS success model and suggests that the dimensions of user satisfaction and attitude toward the website are dependent variables (Chen, Rungruengsamrit, Rajkumar, \& Yen, 2013).

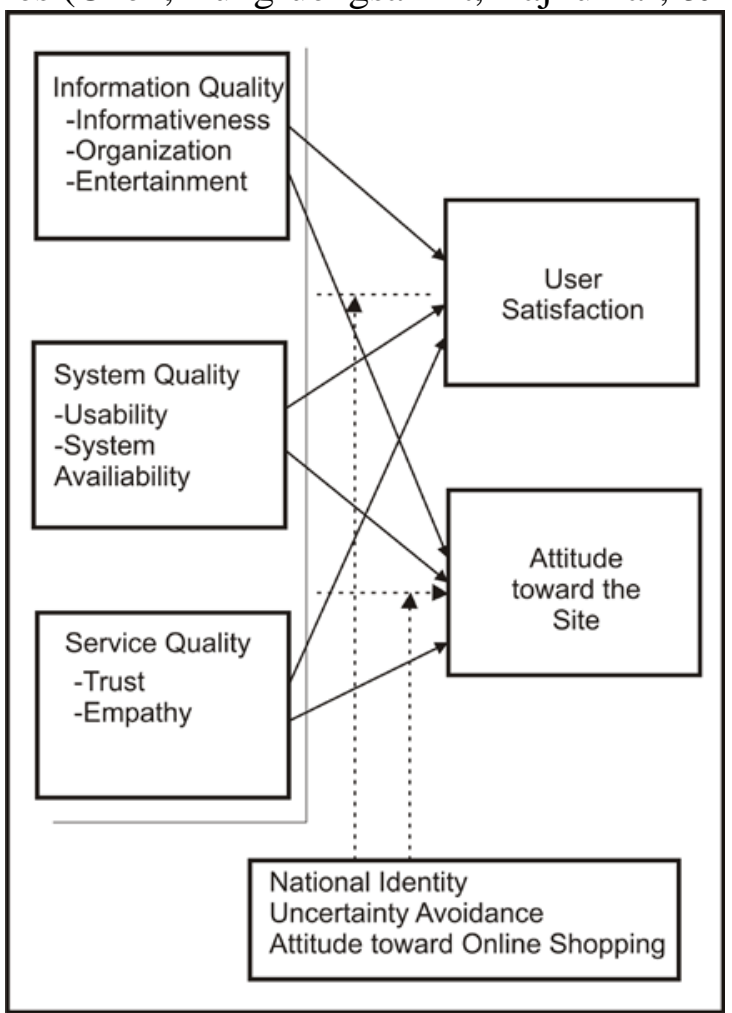

Figure 3. Chen et al. Model (2013) (Chen et al., 2013, p. 346)

The fourth sample model which is used to build the conceptual model of this study is Wixom \& Todd's (2005) model developed by B.H. Wixom \& P. Todd in 2005. System Quality and Attitude dimensions is integrated into this study's conceptual model from this model which is seen in Figure 4 (Wixom \& Todd, 2005). 


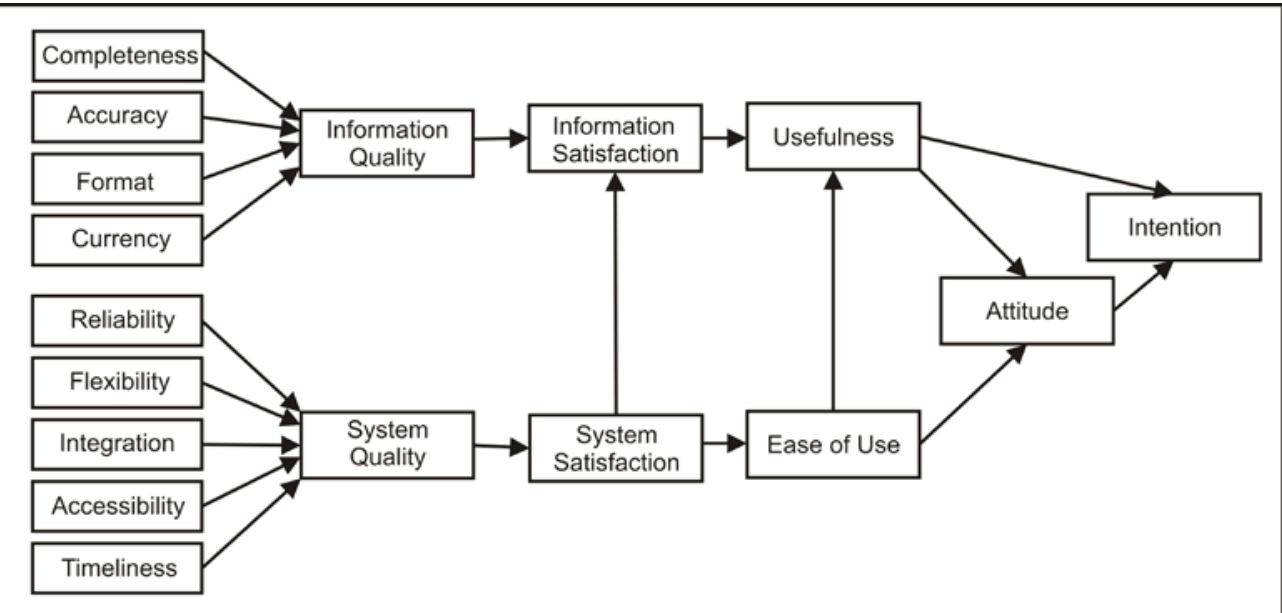

Figure 4. Wixom \& Todd Model (2005) (Wixom \& Todd, 2005, p.90).

The research model of this paper is based on the following four dimensions: System Quality, Attitude toward the Site, User Satisfaction and Net Benefit. Definitions of these dimensions are as follows: System Quality means characteristics of an information system such as ease of use, system flexibility and availability (Petter, DeLone, \& McLean, 2008). Attitude toward the site means behavioral intention to use the web site and purchase at the web site (Chen, Rungruengsamrit, Rajkumar, \& Yen, 2013). User satisfaction means the level of satisfaction of the users of the web site (Petter, DeLone , \& McLean, 2008). Net benefit means the extent to which contribution of the web site to the benefits of users (Petter, DeLone, \& McLean, 2008).

\section{Hypotheses Development}

\section{The Effect of System Quality on User Satisfaction}

The functionality of executive information systems is a measure of system quality. The effect of system quality on user satisfaction was statistically significant (Gelderman, 2002). Ease of use perception of users has a significant effect on user satisfaction (Devaraj, Fan, \& Kohli, 2002). The system firmness of the web site has a significant effect on user satisfaction (Kim, Lee, Kwanghee, \& Lee, 2002). System quality effects the level of user satisfaction (Kulkarni, Ravindran, \& Ronald, 2007).

Effect of system quality on user satisfaction was supported in DeLone and McLean IS Success Models in 1992 and 2008 (Figure 1-2). Also, this effect was supported in Chen 2013 model. The research model in this paper suggests that system quality has a positive effect on user satisfaction. Therefore, the following hypothesis is developed:

$\mathbf{H}_{\mathbf{1}}$ : System Quality has a positive effect on User Satisfaction 


\section{The Effect of System Quality on Attitude toward the Web Site}

System usability has a positive effect on attitude toward the web site (Chakraborty, Srivastava, \& Warren, 2004). The effect of system quality on intention to use was statistically significant (Petter, DeLone, \& McLean, 2008). The effect of system quality on attitude toward the web site was statistically significant. Attitude toward the web site means a behavioral intention to use the web site (Chen, Rungruengsamrit, Rajkumar, \& Yen, 2013). The research model in this paper suggests that system quality has a positive effect on attitude toward the web site. Therefore, the following hypothesis is developed:

$\mathbf{H}_{2}$ : System Quality has a positive effect on Attitude toward the Web Site.

\section{Mediator Role of User Satisfaction on the Effect of System Quality on Net Benefit}

Mediator role of user satisfaction on the effect of system quality on net benefit was statistically significant. First of all, system quality has a positive effect on user satisfaction and then user satisfaction has a positive effect on net benefit (Petter, DeLone, \& McLean, 2008). The research model in this paper suggests that user satisfaction has a mediator role on the effect of system quality on net benefit. Therefore, the following hypothesis is developed:

$\mathbf{H}_{3}$ : User Satisfaction has a mediator role on the effect of System Quality on Net Benefit

\section{Mediator Role of Attitude toward the Web Site on the Effect of System Quality on Net Benefit}

Attitude toward the web site means a behavioral intention to use the web site (Chen, Rungruengsamrit, Rajkumar, \& Yen, 2013). Mediator role of intention to use on the effect of system quality on net benefit was statistically significant (Delone \& McLean, 2003).

The research model in this paper suggests that attitude toward the web site has a mediator role on the effect of system quality on net benefit. Therefore, the following hypothesis is developed:

$\mathbf{H}_{\mathbf{4}}$ : Attitude toward the Web Site has a mediator role on the effect of System Quality on Net Benefit

\section{Research Method}

The main research questions are determining the mediator effect of users' attitude toward the website and user satisfaction on the effect of system quality on net benefit and understanding the indirect effect of system quality on net benefit. This research which is a descriptive cross-sectional 
research analyzing quantitative data collected by using a five point Likert scale. Structural Equation Model is used to analyze the data and test the hypotheses of the theoretical model which has a multi-variable statistical method. Nowadays, Structural Equation Model is a statistical method which has been widely used due to measuring direct and indirect relationships between variables in a single model (Meydan \& Şeşen, 2011). According to Structural Equation Model, traditional methods are insufficient for correcting measurement errors (Byrne, 2010). It tests whether the hypotheses of the model are statistically significant or not after determining the reliability and validity of Likert type ordinal scales. SPSS and AMOS statistics programs are used for analyzes. The research model which is created by deriving the models in the literature is explained in conceptual framework section and seen in Figure 5.

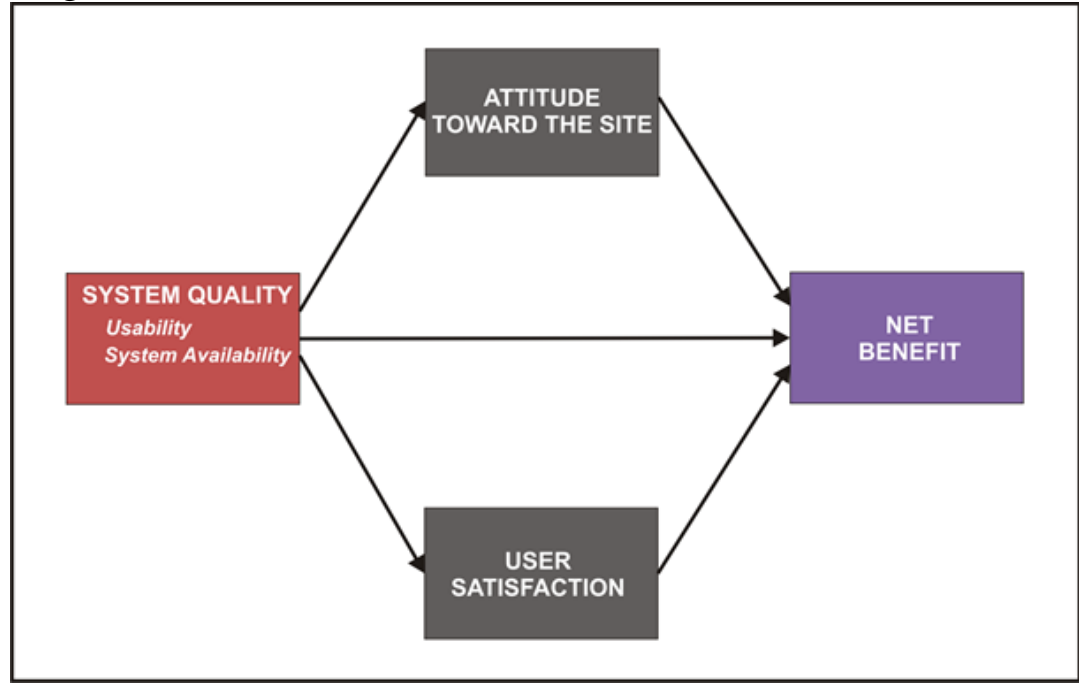

Figure 5. Research Model

\section{Measures and Sampling}

To test the above hypotheses, we used the scales adopted from prior studies for the measurement of dimensions. We measured 5 dimensions by using 5 point Likert scales ranging from strongly disagree to strongly agree. The scales which were developed by Chen et al. (2013) were used for System Quality, Attitude toward the Web Site and User Satisfaction dimensions. The scale which was developed by Wu and Wang (2006) was used for Net Benefit dimension.

The data was collected via online questionnaire. The sample of this study is 407 people who purchase goods or services from e-commerce web sites. According to frequency distribution results, $54.8 \%$ of the respondents are female, $40.2 \%$ of them have university degree and $41.5 \%$ of them are between 25-35 years old. 


\section{Validity and Reliabilty of the Scales}

First of all, CFA and reliability analysis were conducted in order to assess validity and reliability of the measures. CFA results indicated the model fits adequately: $\chi 2 / \mathrm{DF}=3.790, \mathrm{CFI}=0.920$, IFI=0.921, RMSEA= 0.083. CMIN is The Likelihood Ratio Chi-Square Test.

Table 1. Confirmatory Factor Analysis Results

\begin{tabular}{cccc}
\hline Factors & Items & $\begin{array}{c}\text { Standardized } \\
\text { Regression } \\
\text { Weights }\end{array}$ & $\begin{array}{c}\text { Unstandardized } \\
\text { Regression } \\
\text { Weights }\end{array}$ \\
\hline \multirow{3}{*}{ Usability } & Use1 & 0.760 & 1.00 \\
& Use2 & 0.786 & 1.10 \\
& Use3 & 0.647 & 0.80 \\
\hline \multirow{3}{*}{ System Availability } & Sa1 & 0.912 & 1.00 \\
& Sa2 & 0.807 & 0.91 \\
& Sa3 & 0.663 & 0.62 \\
\hline \multirow{3}{*}{ Attitude toward the } & Ats1 & 0.717 & 1.00 \\
Site & Ats2 & 0.747 & 1.13 \\
& Ats3 & 0.847 & 1.11 \\
& Ats4 & 0.763 & 1.10 \\
\hline \multirow{2}{*}{ User Satisfaction } & Us1 & 0.761 & 1.00 \\
& Us2 & 0.831 & 1.09 \\
& Us2 & 0.941 & 1.25 \\
& Us4 & 0.818 & 1.06 \\
\hline \multirow{2}{*}{ Net Benefit } & Nf1 & 0.772 & 1.00 \\
& Nf2 & 0.630 & 0.99 \\
& Nf3 & 0.818 & 1.15 \\
& Nf4 & 0.646 & 0.95 \\
\hline
\end{tabular}

$\mathrm{p}<0.01$ for all items

This test shows the compatibility of the anticipated model and acquired a model. A CMIN/DF ratio is very close to threshold level of 3 (Meydan \& Şeşen, 2011). As shown in Table 1, standardized regression weights of each items are larger than 0.5 and significant. Reliability results are well beyond the threshold Cronbach $\alpha$ value (0.7) as shown Table 2 . AVE results are higher than 0.5 treshold as shown in Table 2 (Fornell \& Larcker, 1981).

\section{Analysis Results}

The compatibility of the model and the data are evaluated according to fit indices. CMIN/DF, CFI (the comparative fit index), IFI (the incremental fit index), RMSA (the root-mean-square error of approximation) are the recognized scales in the literature (Akgün, İnce, İmamoğlu, Keskin, \& Kocoğlu, 2014). 
CFI fit indice which is an incremental fit statistic is tested using the independent model where there is not any relationship among the parameters and compares saturated models. It takes values between 0 and 1 . The values greater than 0.90 indicate good results (Bayram, 2013).

Correlations among the variables should be verified to test mediator roles of the mediating variables (Baron \& Kenny, 1986). Correlations among the variables are significant as shown in the Table 2.

Table 2. Correlation of the Dimensions

\begin{tabular}{|c|c|c|c|c|}
\hline Variables & 1 & 2 & 3 & 4 \\
\hline 1. System Quality & - & & & \\
\hline 2. User Satisfaction & $0.575^{*}$ & - & & \\
\hline 3. Attitude Towards the Site & $0.566 *$ & $0.677^{*}$ & $0.709 *$ & \\
\hline Cronbach $\alpha$ & 0.821 & 0.901 & 0.848 & 0.808 \\
\hline Composite Reliability (CR) & 0.895 & 0.905 & 0.853 & 0.810 \\
\hline Average Variance Extracted (AVE) & 0.589 & 0.706 & 0.593 & 0.520 \\
\hline
\end{tabular}

Three models are developed to test the mediator effect. Final model is shown in Figure 6 and results of the hypotheses are shown in Table 2.

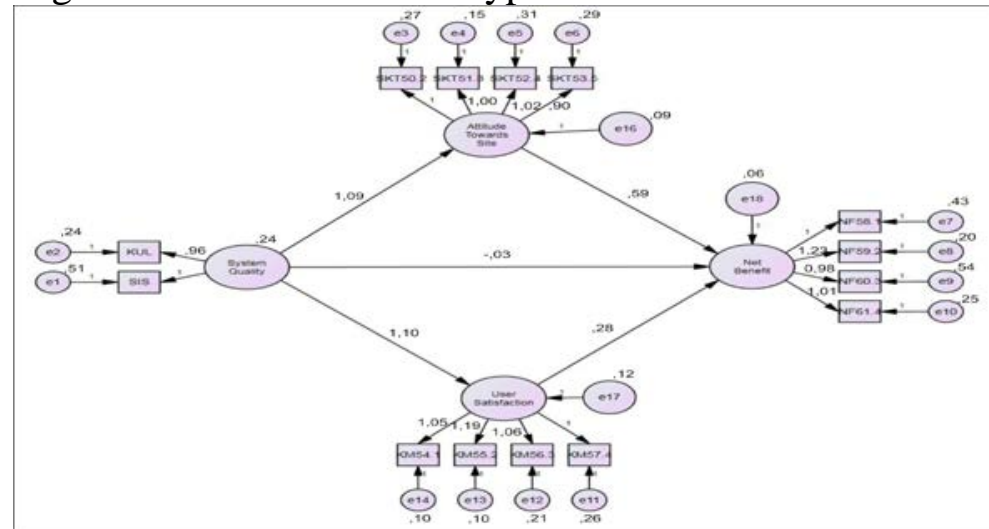

Note: $\chi 2 / \mathrm{DF}=3.750, \mathrm{CFI}=0.944, \mathrm{IFI}=0.944, \mathrm{RMSEA}=0.082$

Figure 6. Model 3 Results of SEM Analysis

Table 2. Hypotheses Results

\begin{tabular}{cccc}
\hline Relationship & Model 1 & Model 2 & Model 3 \\
\hline System Quality $\rightarrow$ Net Benefit & $0.701^{*}$ & & $-0.03^{* *}$ \\
System Quality $\rightarrow$ User Satisfaction & & $0.733^{*}$ & $0.839^{*}$ \\
Sytem Quality $\rightarrow$ Attitude Toward Site & & $0.487^{*}$ & $0.880^{*}$ \\
User Satisfaction $\rightarrow$ Net Benefit & & & $0.331^{*}$ \\
Attitude Toward Site $\rightarrow$ Net Benefit & & & $0.651^{*}$ \\
\hline & $\chi^{2 / \mathrm{df}=4.039,}$ & $\chi 2 / \mathrm{df}=3.678$, & $\chi 2 / \mathrm{df}=3.750$, \\
Model fit indices & CFI $=0.974$, & CFI $=0.967$, & CFI $=0.944$, \\
& IFI $=0.974$, & IFI $=0.967$, & IFI $=0.944$, \\
& RMSEA $=0.087$ & RMSEA $=0.081$ & RMSEA $=0.082$ \\
\hline
\end{tabular}

Note: Path coefficients are standardized.

${ }^{*} \mathrm{p}<0.01 * *$ Insignificant 


\section{Conclusion}

Models which were previously tested in the literature were utilized to create a new conceptual model to examine the mediator roles of attitude toward the web site and user satisfaction on the effect of system quality on net benefit in this paper. A new conceptual model for web site success is developed by including dimensions of the tested previous models. System quality is one of the important antecedent of perception of net benefit for customers of B2C web sites. Thus, this paper focused on the effect of system quality on net benefit. The effect of system quality on net benefit has been modeled through user satisfaction in the literature. Some models included attitude toward the web site as another mediator to examine this effect. Therefore, the research model suggests that attitude toward the web site and user satisfaction play mediator roles on the effect of system quality on net benefit in this paper. It is statistically proved that attitude toward the web site and user satisfaction play mediator roles on the effect of system quality on net benefit as a result of the analysis. This result shows that system quality does not directly create net benefit perception of the users. System quality has an effect on net benefit through attitude toward the web site and user satisfaction.

\section{References:}

Akgün, A. E., Ince, H., Imamoğlu, S.Z., Keskin, H., \& Kocoğlu, I. (2014). The Mediator Role of Learning Capability and Business Innovativeness Between Total Quality Management and Financial Performance. International Journal of Production Research, 52(3), pp. 888-901.

Bayram, N. (2010). Yapısal Eşitlik Modellmesine Giriş: AMOS Uygulamaları. Bursa: Ezgi Kitabevi.

Baron, R.M., \& Kenny, D.A. (1986). The Moderator-Mediator Variable Distinction in Social Phychological Research: Conceptual, Strategic and Statistical Considerations. Journal of Personality and Social Phychology, 51(6), pp. 1173-1182.

Byrne, B.M. (2010). Structural Equation Modeling with AMOS: Basic Concepts, Applications, and Programming. $2^{\text {nd }}$ Ed. New York: Routledge Taylor \& Francis Group.

Canpolat, Ö. (2001). E-Ticaret ve Türkiye'deki Gelişmeler. Ankara: Sanayi ve Ticaret Bakanlığı Hukuk Müşavirliği.

Chakraborty, G., Srivastava, P., \& Warren, D.L. (2005). Understanding Corporate B2B Web Sites' Effectiveness from North American and European Perspective. Industrial Marketing Management, 34(5), 420-429.

Chen, J.V., Rungruengsamrit, D., Rajkumar, T.M., \& Yen, D.C. (2013). Success of Electronic Commerce Web Sites: A Comparative Study in Two Countries. Information \& Management, 50(6), pp. 344-355. 
Delone, W.H., \& McLean, E.R. (1992). Information Systems Success: The Quest for the Dependent Variable. Information Systems Research, 3(1), pp. 60-95.

Delone, W. H., \& McLean, E.R. (2003). The DeLone and McLean Model of Information Systems Success: A Ten-Year Update. Journal of Management Information System, 19(4), pp. 9-30.

Deniz, R.B. (2001). İşletmeden Tüketiciye İnternette Pazarlama ve Türkiye'deki Boyutları. İstanbul: Beta.

Devaraj, S., Fan, M., \& Kohli, R. (2002). Antecedents of B2C Channel Satisfaction and Preference: Validating e-Commerce Metrics. Information Systems Research, 13(3), pp. 316-333.

Fornell, C., \& Larcker, D. F. (1981). Evaluating Structural Equation Models with Unobservable Variables and Measurement Error. Journal of Marketing Research, 18(1), pp. 39-50.

Gelderman, M. (2002). Task difficulty, task variability and satisfaction with management support systems. Information \& Management, 39, pp. 593-604.

Hsia, T.-L., Wu, J.-H., \& Li, E.-Y. (2008). The E-Commerce Value Matrix and Use Case Model: A Goal-Driven Methodology for Eliciting B2C Application Requirements. Information \& Management, 45, pp. 321-330.

Kim, J., Lee, J., Kwanghee, H., \& Lee, M. (2002). Business as Buildings: Metrics for the Architectural Quality of Internet Businesses. Information Systems Research, 13(3), pp. 239-254.

Kulkarni, U.R., Ravindran, S., \& Freeze, R. (2007). A Knowledge Management Success Model: Theoretical Development and Empirical Validation. Journal of Management Information Systems, 23(3), pp. 309347.

Laudon, K.C., \& Traver, C.G. (2012). E-Commerce 2012: Business, Technology, Society. $8^{\text {th }}$ Ed. Harlow: Pearson.

Meydan, C.H., \& Şeşen, H. (2011). Yapısal Eşitlik Modellemesi AMOS Uygulamaları. Ankara: Detay Yayıncılık.

Mira, B. P. (2010). Validity of Delone and McLean's Model of Information Systems Success at the Web Site Level of Analysis. Dissertation Submitted to the Graduate Faculty of the Louisiana State University. US: Louisiana State University, May.

Petter, S., DeLone, W., \& McLean, E. (2008). Measuring Information Systems Success: Models, Dimensions, Measures, and Interrelationships. European Journal of Information Systems, 17, pp. 236-263.

Pilik, M. (2013). Selected Factors Influencing Customers' Behaviour in e-Commerce on B2C Markets in the Czech Republic. Proceedings of the European Conference on Information Management \& Evaluation, pp. 121128. 
Sarısakal, M.N., \& Aydın, M.A. (2003). E-Ticaretin Yeni Yüzü Mobil Ticaret. Havacilık ve Uzay Teknolojileri Dergisi, 1(2), pp. 83-90.

Sözer, E.G. (2009). Postmodern Pazarlama: Marka Çağında Liderlik İçin PİM Modeli. İstanbul: Beta Yayıncilık.

Tang, Q., \& Huang, J. (2008). Impact of Web Site Functions on E-Business Success in Chinese Wholesale and Retail Industries. Tsinghua Science and Technology, 13(3), pp. 368-373.

Wixom, B. H., \& Todd, P. (2005). A Theoretical Integration of User Satisfaction and Technology Acceptance. Information Systems Research, 16(1), pp. 85-102.

Wu, J.-H. W., \& Wang, Y.-M. (2006). Measuring KMS Success: A Respecification of the DeLone and McLean's Model. Information \& Management, 43, pp. 728-739. 